\title{
Curricular transposition in citizenship education
}

\author{
Theory and Research in Education, 6 (2) 153-172
}

Tristan McCowan

\begin{abstract}
The considerable debate in recent years on the aims of citizenship education has not been accompanied by an equally substantial discussion on the educational processes involved. This article puts forward a theoretical framework, referred to as 'curricular transposition', for understanding the complex task of realizing normative ideals of citizenship through education. The framework highlights four stages in the educational process: the ideals and aspirations underlying an initiative; the curricular programme designed to achieve them; the programme's implementation in practice; and its effects on students. The 'leaps' between these stages - involving movement between ends and means and between ideal and real-are highly problematic. These ideas are explored in the context of an empirical case: the Voter of the Future programme in Brazil. Disjunctures are observed at the different stages - in particular, a lack of 'harmony' between ends and means, and a lack of teacher ownership of the initiative in the process of implementation - leading to divergence between the initial aims and actual effects. Finally, broader implications of the curricular transposition framework for citizenship education are drawn out.
\end{abstract}

\section{Introduction}

The aim of developing forms of citizenship through education is as old as the existence of public education systems themselves. Formal education in many countries has been closely linked to the galvanizing of loyalty to the state and the building of a national ideology (Green 1990). In recent times, schools have taken on a more progressive role of developing young citizens for democratic participation, and enhancing understanding of their rights as citizens. A prominent example of this is the introduction into the National Curriculum of England and Wales of a statutory requirement for Citizenship Education.

This event, and the continuing presence of forms of civic education in the curricula of other countries such as the USA, has led to a burgeoning of normative literature in English on the subject. The majority of this writing focuses on the desirability or need for citizenship education, the conceptions of citizenship underlying it and on its proposed aims (e.g. Callan 1997; Galston 1989; Kymlicka 2003; McLaughlin 1992). Given the contested nature of citizenship, it is understandable and desirable that a heated debate on the existence and goals of citizenship education should occur. However, this focus has not been accompanied by an equally substantial debate on the educational processes organized to attain them. The impression is often given that 
once appropriate civic goals have been determined, achieving them will be relatively straightforward.

In addition to this normative literature, there is now substantial empirical research on citizenship education initiatives around the world, including studies on official curricula (e.g. Davies \& Issitt 2005; Osler \& Starkey 2001; Torney-Purta 1999), implementation in practice (e.g. Cogan \& Morris 2001; Walkington \& Wilkins 2000) and evaluations (e.g. Finkel 2002; Gastil 2004; McAllister 1998; Niemi \& Junn 1998). However, there is little discussion of the links between these different perspectives, and between the practices of citizenship education and the normative ideals outlined above. In consequence, the processes involved, and their chances of success, remain largely obscure.

In response, this article puts forward an original framework for understanding the complex processes involved in the promotion of citizenship through education. The framework, called curricular transposition, traces the movement of the curriculum through four stages: first, the initial aspirations or ideals that motivate educational undertakings; second, the curricular programmes stemming from them; third, their implementation in practice; and finally, the effects they have on students. The framework highlights the different transformations that occur between the stages, and the disjunctures that exist in many initiatives. This study develops the analysis of a previous article (McCowan 2009), which focuses on the first of these movements, assessing the relationship between ends and means.

This article does not put forward a normative argument as to how citizenship education initiatives should progress in the light of these difficulties (although there will inevitably be normative implications emerging from the analysis). What is proposed here is a framework for understanding their dynamics, one which can be used to analyse current experiences, particularly as regards the problematic movement between the ideal and the real, and between ends and means. The study will draw on empirical research to illustrate these different stages of the process of curricular transposition. The research consists of a case study of 'Voter of the Future', a programme aiming to promote democratic citizenship amongst young people in Brazil. As well as having intrinsic interest, the case illustrates the problematic disjunctures that can occur between the different stages. Before discussing the empirical context further, there will first be a fuller outline of the notion of curricular transposition.

\section{From didactic transposition to curricular transposition}

'Curricular transposition' is a mechanism for understanding the processes through which educational undertakings are created and implemented. It draws on the concept of didactic transposition' developed by Francophone theorists such as Chevallard (1985), Conne (1986), Perrenoud (1986; 1992) and Tochon (1991). Didactic transposition refers to the ways an item of knowledge changes as it becomes part of a curricular programme. For example, Einstein's theory of relativity does not exist in the same form in schools as it does in the scientific community: it undergoes certain modifications when moving from the latter to the former. In the theory, a distinction is made between 'external' and 'internal' transposition, the former referring to the transposition of knowledge into school curricula as outlined above, and the latter to the transposition of the official curriculum into the content taught in practice by teachers (Perrenoud 1998). Tochon (1991) calls the latter 'pedagogical transposition'. The concept of didactic transposition was initially developed in relation to didactics of mathematics, and is most applicable to this area and to the natural sciences, yet Perrenoud (1998) and others have proposed extensions to the theory to include those school disciplines that stem from social practices rather 
than factual knowledge. There are clear points of contact between didactic transposition and Bernstein's (1996) notions of the recontextualisation and reproduction of discourses from the field of knowledge production in the school setting.

However, the fact that didactic transposition takes knowledge (or, in some cases, practices) as its starting point, means that the theory works well in relation to individual subjects, where the movement of knowledge from society to school can easily be seen. Yet, it is not as readily applicable to the curriculum as a whole, being a collection of various areas chosen on the basis of fundamental beliefs and values. It is necessary, therefore, in an analysis of transposition, to take account of this previous stage at which there exists an ideal of a human being or society to be developed. Educational undertakings have an element of purpose that is not captured in didactic transposition. This paper, therefore, extends the ideas of the didactic transposition theorists to encompass a broader conception of education. Curricular transposition refers to the materialization or concretization of aspirations or ideals into educational programmes, approaches and activities.

The figure below shows curricular transposition in graphic form. The second and third stages correspond broadly to the common distinction made between the 'official' curriculum and the 'unofficial' or 'taught' curriculum, and the fourth stage to the 'achieved curriculum' (e.g. Mullis et al. 2005). Perrenoud (1998) outlines a similar scheme showing the movement between 'current knowledge and practices in society', 'formal curriculum, objectives and programmes', 'real curriculum, content and teaching' and 'effective and durable learning of the pupils' [author's translation]. (Later in the article he replaces this model with another more complex one revolving around the notion of competencies). However, Perrenoud's model represents a linear relation and does not show the movement between planes of ideal/real and ends/means. A two-dimensional model is therefore proposed in its place, incorporating these aspects, and focusing on the emergence of curricula from underlying aspirations, rather than 'knowledge and practices' .

The following figure shows the four stages:

ENDS MEANS

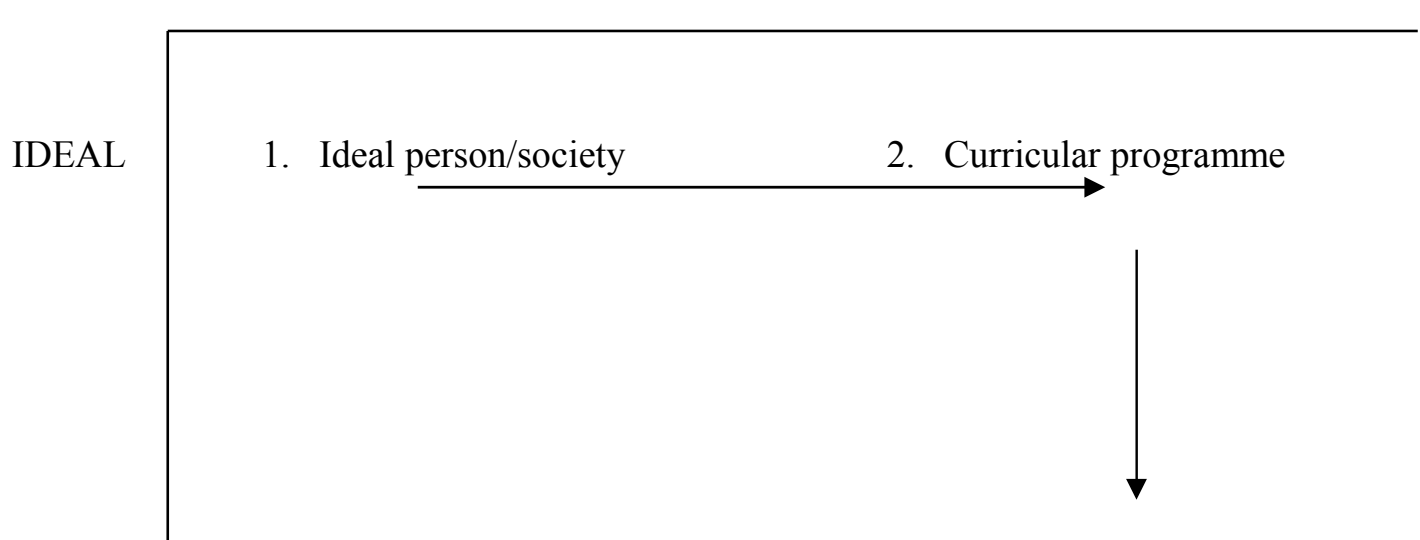

REAL 4. Effects on students 3. Implemented curriculum 
This scheme applies generally to the curriculum, but will here be discussed in relation to citizenship education specifically. In the first stage, there is a conception of a valued end (in this case citizenship). From that, an ideal educational programme is created, which is then modified as it is implemented in a real context. The implemented programme then influences the students (not necessarily in the way originally envisaged), affecting their abilities and identities as citizens. By way of an example, an educational body might have a conception of valued citizenship as loyalty to the nation (1), conceive that this would best be promoted through inspiring works of national literature (2), implement this through schools although with some teachers presenting critiques of the works in question (3), leading to mixed effects among the students (4).

This process involves 'leaps' between different planes: from that of ends to that of educational means (in the case of 1-2 and back in 3-4) and from the ideal to the real (in the case of 2-3). These leaps are highly problematic. An ideal of citizenship is hard to achieve through education due to constraints on devising educational methods to realize it, on implementing those methods in an institution or other setting, and on obtaining the desired change in students. (In the rest of the article the term 'stage' is used to denote the form of the curriculum at a particular point in the process - e.g. ideal programme, implemented curriculum etc. - and 'leap' to denote the movement between the stages).

Acknowledging the difficulties involved in these leaps is key to understanding the apparent disjunctures between the educational practices and experiences going by the name of citizenship education, and the political aspirations on which they are based. The process will now be explored in the empirical context of the Voter of the Future initiative in Brazil.

\section{The Voter of the Future Programme}

Voter of the Future is an educational initiative designed to combat the serious malfunctionings of the Brazilian democratic system. While the country has had democratic governments since 1985, when the military dictatorship in place since 1964 finally fell, the formal guarantees of citizenship are not matched by effective realization in practice. Elections are commonly characterized by 'clientilism' (exchange of political support for favours) and outright vote-buying, with power at municipal and state levels often held in the hands of colonels (wealthy landowners), who refer to their constituencies as 'corrals'. Large parts of the population - particularly the black and indigenous communities, and inhabitants of the favelas (shantytowns) - are marginalized from political participation, and have their political, civil and social rights routinely abused (Bethell 2000; Gentili \& Frigotto 2000; Taylor 2004).

The Brazilian context presents an extreme instance of socio-economic inequality and political marginalization, but also concerted attempts to respond through political empowerment (Gentili $\&$ McCowan 2003). The National Curricular Parameters introduced in the late 1990s have elements relating to democratic citizenship, yet their implementation across the system is irregular due to the high degree of decentralization. Taking advantage of this feature of the system, a number of social movements, NGOs and local governments have attempted to address this political marginalization through their own educational interventions (e.g. Bartlett 2005; Gandin \& Apple 2002; McCowan 2006; Myers 2007; Stromquist 1997).

One recent initiative aiming to promote effective citizenship is Voter of the Future ${ }^{2}$ (VF). The programme was designed initially by the Brazilian Supreme Electoral Tribunal (SET) in November 2002, inspired by a similar initiative in Costa Rica. The motivation for the initiative was the need to develop young people's abilities to be responsible and critical citizens, given the 
problems with the functioning of liberal democracy in Brazil referred to above. In August 2003 a meeting of representatives from electoral bodies and from UNICEF in Brasília produced a booklet entitled Learning to be a Citizen, outlining the following main aims of the program:

- To strengthen the citizenship of children and adolescents aged 10-15 who are enrolled in the school system.

- To encourage young people aged 16 and $17^{3}$ to participate in the democratic process as enabled by the Citizen Constitution of 1988 , facilitating their enrolment in the coming elections.

- To alert young people to the vices which distort and contaminate the objective and essence of the right to vote, making them aware of the ethics of politics and the exercising of the vote.

- To inform young people of good and bad electoral practice on the part of candidates and parties, with reference to current electoral legislation.

- To guarantee young people the right to expression and opinion on elections, an important moment of the democratic life of the country.

- To equip and mobilize the young people involved in the initiative for the conscious and free exercising of the vote, guaranteeing them an emancipatory citizenship in the future.

(SET 2003: 5)

Unsurprisingly, given its origins in the judiciary, the initiative has a strongly legalistic conception of citizenship and citizens' rights. The legal bases of the programme are the Federal Constitution of 1988, the Brazilian Statute of the Child and the Adolescent of 1999, and the 1989 UN Convention on the Rights of the Child.

The initiative is implemented by the Regional Electoral Tribunals (RETs), one in each state of the country, with schools adhering on an optional basis. There are no external funds for the programme, and its implementation therefore depends on the priorities and budgetary constraints of each RET. The programme is intended to be a partnership between different sectors of society, particularly: officials of the electoral system, officials of the child and adolescent justice system, schoolteachers, NGOs, human rights activists and volunteers (SET 2003: 6). However, in most cases, the partnership is restricted to the RET and a few selected schools in the vicinity. The programme has been designed on a centre-periphery model, initiated by a national body and disseminated to the regions. There is significant difference in the uptake of the individual states, with substantial activities in some, and only a token acknowledgement of the initiative in others. As yet, no research studies or formal evaluations have been carried out, although a summary of the initiative's aims can be found in Burges (2006).

The case study forms part of a larger research project, involving two other cases of education for citizenship in Brazil (the Landless Movement and the Plural School), with contrasting approaches (McCowan 2009). This article will only discuss data from the VF programme. In 2005-2006, visits were made to five states; one of these was chosen for in-depth research. (The location of the research will remain anonymous as, given the small scale of the initiative, the anonymity of the participants would otherwise be at risk). The state in question is a sparsely populated one in the Amazon region, showing a number of the challenges facing Brazilian democracy in general: nepotism, vote-buying, clientilism, limited literacy skills among voters and restricted access to reliable information. It is heavily dependent on public sector employment, much of which is allocated in return for political support, meaning that many people's livelihoods depend on the election of particular candidates. This state was chosen for the research as, in spite of these significant challenges, the VF programme had been more firmly established than elsewhere in the 
country. A total of 10 primary and secondary schools (eight of these public and two private) were involved in the state capital.

In order to obtain both depth and breadth in the treatment of the case, different forms of qualitative research were used, with data collected in the RET and in five schools (two private and three public). Semi-structured interviews were conducted with RET officials, and in each of the five focus schools, with the headteacher, one classroom teacher and three groups of students aged 11-18 (a total of 28 interviews). Official documents and pedagogical materials were collected at national, state and school levels. Lastly, participant observations were carried out of activities such as lectures, debates and training sessions.

The documentary data ${ }^{4}$ was analyzed to determine the underlying moral and political orientations of the initiative, and identify the official curriculum programme. The interviews provided personal views and understandings of citizenship, and the perspectives of different actors on the process and effects of implementation. Observations provided perspectives on the interactions of participants in the programme, and the responses of students to the activities undertaken. On account of the limited time-scale of the research, the study can provide only tentative conclusions about the programme's effects.

\section{The first leap: from ends to means}

This section will be brief, as this phase of curricular transposition has been dealt with in depth in a previous article (McCowan 2009). The choosing of means in order to attain certain ends in education is not a straightforward process. There are various bases on which this choice can occur, including empirical evidence, authority or tradition, moral imperative or logical connection. In addition to these rationales, it is possible to determine the 'proximity' of ends to means, i.e. the extent to which they are unified or separate. If means and ends are separate, then there is just the link of intended causality between the two. However, there can also be 'harmony' between them. In this way, a school that aims to form democratic citizens will undertake its educational and institutional functions in a democratic manner. In some instances, ends and means can be unified completely. This occurs when the process of learning is carried out through the exercising of the end: in this case, when the development of citizenship capacities occurs through the act of citizen participation itself.

Particular forms of relationship can be observed in the VF programme. As seen above, the aspirations of the programme are to form citizens capable of making informed, critical and responsible choices in elections. Learning to be a Citizen is unequivocal in the importance given to political participation, its first line being, "The project Voter of the Future was conceived in order to stimulate the citizen participation of children and adolescents in the electoral process" (p.5). The participation valued by the programme, however, does not extend to social movementtype activities, or direct forms such as campaigning and protesting. Yet, there is some awareness of the limitations of voting - the programme refers to the "restricted conception of citizenship that is the exercising of the vote" (RET 2005: 4) - and attention to wider citizen rights and responsibilities.

In terms of the means of achieving these ends, the main vehicle for the development of participation is the mock election carried out in schools, which can either parallel the real elections at municipal, state and federal levels, or alternatively focus on election of students for school offices. Importantly, a few of those involved in the project also have the chance to participate not only as voters but also as candidates, preparing and delivering a political 
campaign, developing proposals, and implementing them once elected. Other activities include lessons, lectures and seminars; visits to legislative chambers, the judiciary and other organs of public administration; and essay, music and design competitions.

The relationship between means and ends in this case, therefore, is one of 'separation', according to the categorization of 'proximity' referred to above. There is little evidence of harmony between the two, in terms of attempts to use democratic educational practices in order to achieve the democratic goals. There is mention of 'interactive pedagogy', but no introduction of elements such as school councils, or other forms of participation within the school that prefigure a democratic society. In addition, there is no evidence of 'unification'. The activities engaged in by the students are preparation for future citizenship, not an exercising of it in the present. The preferred form of educational activity is the simulation, in particular the mock election which is intended to develop students' skills for future participation in the real elections.

In general, there appears to be a degree of arbitrariness in the choice of means. There seems to be no clear reason, for example, for choosing essay writing competitions over other forms of educational activity as a means of developing democratic citizenship. In the programme literature, both the aims and activities are clearly laid out, but there is no indication as to the connection between the two. This common characteristic of citizenship education programmes represents the first disjuncture in the process of forming democratic citizens.

\section{The second leap: implementation}

This phase of transposition takes us from the realm of the ideal to the real, from a curricular programme as it exists as a set of ideas to a set of educational practices, and from the general to the local. In this passage, it undergoes transformations due to number of factors, including the influences of the educators, those of the educational institution, and those of the wider society in which the educational undertaking takes place. A much more extensive literature exists on this phase than the first one (e.g. Benavot \& Resh 2003; Fullan \& Pomfret 1977; Snyder et al. 1992). There is no space here for a full analysis of implementation of the VF programme. Instead, the focus will be on two key causes of disjuncture: the disengagement of teachers from the programme, and the wider political constraints.

As a whole, implementation of the VF programme was problematic. In some cases individual teachers and schools did use the initiative as a stimulus for their existing practice so as to bring students into contact with electoral debates and current affairs in general. Yet, while there were examples of inspiring practice, the initiative did not in general manage to integrate itself into the school day and create a significant educational opportunities for students. Efforts were focused on high-profile events such as mock elections and debates, heavily publicized by the RET, but without deeper influences on the curriculum.

Citizenship education is highly dependent on the particular teachers involved, and the compatibility or dissonance between their worldviews and that of the initiative (Walkington \& Wilkins 2000). One factor that restricted implementation of the VF programme in schools was a lack of involvement in and ownership of the programme on the part of teachers. The issues raised in the VF programme are intended to be dealt with by teachers in their regular classes, in addition to the special activities. However, there was very little evidence of this taking place, except in a few instances. One exception was the work of the teacher Glauco ${ }^{5}$ in Amazonas School. He explained: 
We always start the class with what I call the 'daily news item'. They [the pupils] undertake to bring a piece of news that they can get in any source, whether newspaper, the internet or a personal experience that they had. So they prepare a card and we choose a pupil to speak about his or her news item, at the start of the class.... I always try to show to them especially the relation to the public sphere. No one takes an isolated decision that's not going to affect many people. So sometimes they complain about the holes on the road. "Why is it that the roads are full of holes? Because there's no money. But is it really that there's no money? Or is it that the money is being badly spent?"

This teacher's work shows evidence of creative enactment of the programme in the day-to-day curriculum. Yet examples of this were rare. One problem was that involvement was usually limited to a single teacher in each school. Glauco did show the desire to share his work with other teachers, and encouraged them to adopt his practices:

I'm trying to convince my colleagues at least to try something similar or at least to look at the cards [the 'daily news items'] because perhaps we can discover the potential of the people that otherwise we wouldn't perceive.

However, these individual efforts were not enough. Speaking generally about the work with citizenship in the school, he stated:

I think that this project would work better if we could achieve a better harmony between those who are carrying out the project and the other teachers. We still need to sit down and discuss better, to evaluate better ....

The fact that activities were centred on a few figures led to a problem of continuity. The departures of the teachers Anabela and Rita from their respective schools during the course of the research signalled the end of the programme's activities there.

Even those teachers who were involved did not on the whole have a strong link with the project in terms of contact time. Glauco had only two meetings with staff from the RET, for the purpose of 'information exchange'. In addition, the programme lacks a substantial training programme for teachers. The 'multipliers' have occasional sessions at the RET, and electoral judges make some visits to schools, yet the provision is very limited on the whole.

Teachers, then, are not involved in the construction and development of the programme, and are brought in on a limited scale for the purpose of implementation. The disengagement of teachers led to difficulties of integration of the programme into the curriculum as a whole. Despite the aim of the initiative being to provide a major shift in young people's political socialization, the activities were sporadic and in most cases did not bring a significant change to school practice.

A number of external social factors also influenced the way in which the programme was implemented. These included family and community influences on the students and teachers, and their socio-economic level. Another important factor was the political environment in which the schools were located. Being heavily dependent on public funding and offices, and being far from the national centre of power, the state in which the research was carried out is especially characterized by political factionalism and corruption. It also maintains appointment of headteachers by the local government, rather than the school community, leading to instability in schools and a lack of identification with local concerns. Rita had been sacked as headteacher, in her opinion, for her work with the VF programme and her political affiliation in general. 
Teresa and Edson, RET coordinators, expressed concerns about the funding for the programme. There were general cuts in the RET, and, in their view, VF would be the first project to go, on account of opposition to political awareness-raising. As Edson stated, "Conscientization ${ }^{6}$ makes for a lot of hard work!"

One of the issues encountered by teachers at the private schools was that a number of their pupils were children of politicians or influential government officials. This meant that issues which in another context would have been impersonal became at times highly personal. Glauco stated:

So it's always very interesting, because there are many pupils who are relations of politicians. Sometimes someone says something which touches a nerve of someone else, and they jump up and say, "you're saying that because he's your relation". I try to show them, "Look, what we need to understand once and for all is the great lesson of making a distinction between what is public and what is private. I'm not going to defend somebody just because he or she is my relation".

Later he added:

Once we were discussing the use of what is public and they started to say, "It's wrong!" And I took the chance to say, "I have to confess to you that many times I see military police cars leaving policemen's children at school. Then the citizen rings to report a crime: "Oh dear, there's no police car".... My wife says, "Look, you shouldn't say these things"... but we have to show them how things are. We need to show that some things need to be said even though they carry some risk.

This is a courageous position, given the significant power and influence that police and government officials have in Brazil, particularly in 'periphery' towns. Fear of reprisals is likely to discourage discussion of controversial issues in schools in general.

Given that the promoting body is the arbitrator of elections in Brazil, it is essential that the initiative maintains impartiality towards the different political parties: as is stated, "the objective of the programme is not to form opinion or party political affiliation" (RET 2006: 3). Sonia, a head teacher, made it very clear that within her school there was to be no party political discussion - teachers had to leave those kinds of views "at the school gates". The RET even had to censure some activities so as to maintain the position of neutrality:

At the start of the programme we had an experience... there were many posters with the candidates that were going to contest the last presidential election.... So we had to take care to call the teachers of the pedagogical team and tell them, "look, we're going to work with the booklet, not with party political preferences". If you put up... photos of politicians you induce that young person to say whether that politician is any good or not. (Interview with the Judge Antonio)

The pressures towards neutrality meant that students were rarely provided with the opportunity to discuss issues of inequalities and exploitation - discussions that are particularly relevant to the context of Brazil. Instead, the tendency in the programme was to focus on procedure - the process of voting, political institutions and so forth - and steer clear of substantive political debates. The conducting of the types of activities and debates necessary for developing political knowledge and awareness was, therefore, significantly curtailed by the political environment. 
These two aspects of teacher disengagement and political constraints are examples of causes of disjuncture between the intended curriculum and the implemented one. Disjunctures at this point, therefore, can be caused both by characteristics inherent in the programme, and by external factors.

\section{The third leap: effects on students}

Some tangible effects were observed in the VF programme. Students developed knowledge, skills and values in relation to voting and the electoral system. Those who participated clearly took on board the importance of a responsible choice of candidate and the need to keep politicians to account. However, wider influences on democratic attitudes and practices were not apparent. The superficiality of implementation appeared to be reflected in the superficiality of development of the students.

The initiative did appear to have achieved its aims in terms of raising awareness of the vote itself. Students could distinguish between voting based on short-term material gain and that based on long-term benefit to the polity as a whole. As a student in Morães School (12 years old) reported, "It's not voting for that person who is attractive, who puts out adverts, who's going to give you something". In addition, the students enjoyed the process of voting itself. As Glauco states:

Glauco: They adored voting at the machines in the elections. Some even said, "Next year I'm going to make a point of going with my father.

TM: $\quad$ Even without voting?

Glauco: Yes. I think this is very interesting, because at the end of the day it's the road to something which in the future can make them go from a playful thing of using the machine to the more serious thing that it actually is.

An important event for students was the debate with candidates in the RET. The teacher Anabela gave a very positive evaluation of the experience of the debate in 2004:

They [the pupils] were really engaged, they participated... at the time of the debate, they got up and asked questions to the candidates.... there were lots of interesting questions, which were just as good as the television debates..... there were times at which the candidates even were left a bit disconcerted by the questions that they put to them!

This final point was borne out by observation of the debate in 2006 .

A small number of students had a very strong engagement with the programme. Carla, for example, was very positive about its effects:

[L]ike a donkey, he has two things here [pointing to her eyes] so he can only see straight ahead, but when he takes it off he has a wide vision. And I think this happened with many people at the school, you understand?... So he [the student] can choose better, he can vote better.... [A]nd when you give this broader vision to the pupils, they take it home. They debate this with their fathers, with their mothers.

Carla also gave a positive assessment of her own learning in the talk given by Antonio, but affirmed that this was not applicable to all the students: 
Carla: No, we leant a lot of things. The plebiscite, what a referendum is...it was interesting.

TM: $\quad$ Do you think it was a useful experience for everyone?

Carla: I would say that it wasn't for everybody. Because some people go there and they make the most of it, and others go just to clown about.... It was interesting for those who went to absorb everything there was to absorb of the project....

Here use of the term 'absorb' is significant here in terms of the pedagogical approach. The emphasis in the initiative was on the transmission of information, skills and values, and not on participatory construction of knowledge and understanding. As a possible result of this, the majority of the students adopted the discourse of the project, but without internalizing the new values with any depth. In addition, while there were some advances in the students' knowledge and skills in relation to voting, there was little evidence of development of wider citizen capacities. Although the Learning to Be a Citizen booklet emphasizes understanding of rights, there appeared to be little development of the notion in the students, aside from the right to vote itself. As would have been expected from the curricular programme, democratic participation of students in the school was very limited. Schools did not appear to have adopted decision-making bodies for pupils, and there was no evidence of a significant shift in structures or ethos. Neither were there opportunities for the students to participate politically outside the school.

In summary, therefore, the programme was successful in transmitting a set of values in relation to electoral honesty and responsibility. There was an increase in basic knowledge about voting and political processes, an appreciation of the importance of the vote and the relationship between one's choice and the welfare of the country or region, and development of skills in using the voting machine. However, in many cases there was absorption of the discourse of the programme but not necessarily its full internalization. In a minority of cases, there was development of significant skills and knowledge associated with mounting a political campaign and acting as a representative. Yet, there was no significant increasing awareness of or commitment to rights, skills of deliberation or of other aspects of citizen identity or action, and little development of democratic participation outside voting.

What explanations can there be for the gap between the expected or hoped-for results and the actual results? In part this can be attributed to the difficulties of bridging the previous two gaps. Problems in the choice of ideal curricular programme, and in the process of implementation meant that students were not offered the appropriate learning experiences. An example is the pedagogical approach of the programme. It is stated that, "The methodology will consist of interactive classes and/or lectures, with distribution of specific texts and utilization of audiovisual resources" (RET 2004: 7). However, evidence from the students was that these interactive forms of delivery were not being used. One student, Cassia, from Caymmi School remarked:

I think that...lectures are very boring for young people.... [B]y picking up the microphone you are considering yourself superior, with all, all attention centred on you. Lectures for young people have to be in the form of workshops, everyone in a circle, sitting on the same level, speaking on the same level, doing activities. It was a bit boring, so that at the end you weren't really awake. And also young people like to question, if there's no space to question they're not going to pay attention any more. 
Traditional lecturing styles are here seen to be uninspiring for students, and not to provide them with the opportunity to question. A third, and more subtle, point made by Cassia is that the act of picking up the microphone symbolizes a hierarchy of power that is inimical to the type of democratic relation is being promoted (i.e. a 'disharmony' of ends and means).

Another student, Carla, also remarked on problems with the delivery, which she saw as the explanation for the full engagement of only a minority of pupils in the program:

Young people like dynamic activities, something more real, you know, they don't like lectures much, talking, talking, they get bored. If adults get bored then imagine how much young people do.

However, effects on students cannot be explained only in terms of difficulties in establishing the curriculum and implementing it. Students, as human agents, rarely absorb messages exactly as they are presented. They are capable either of rejecting them, or recasting them in a way that was unintended in the original programme. One interview was carried out with secondary level students at Caymmi School, who were presented as being 'less engaged'. Interestingly, while they may have had less involvement in the programme, this was not an indication of lack of involvement with politics, but of reservations about the programme itself:

The idea [of the programme] is great as a political theory, but it could integrate politics in a different way, not making the pupil a simple voter, but rather a politician...because when you've got the critical sense that the building of a square, the paving of the roads is not a favour for you, but an obligation, having this sense, having this notion and knowing that you are a social politician participating in youth movements, you are going to know who to elect, you're going to know who to vote for. (Interview with Cassia)

Later in the same interview, Robson said in relation to the Judge Antonio's talk:

Some things also I didn't agree with.... He spoke about, that...poorer people don't have the awareness to vote...that for a person to vote you have to have structured schooling.... But you see, it's the politicians themselves who don't want this to happen so they can monopolize people. So I think that, I don't believe in anything in politics.... That a person, he's hungry... he's going to vote for whoever helps him at that particular moment, because he's thinking about satisfying his hunger and everything.

Cassia continued:

[P]ublic education... I don't think it's going to get better, because the politicians don't want it, the politicians don't want the young person to have this awareness. That he has, that he knows he has the right to quality education, quality health care, why are they going to improve education?

These more critical attitudes towards politics -- which in many ways show a sophisticated understanding of the political and relations of power in society -- made the students appear disengaged from the programme. While the school interpreted this disengagement as stemming from apathy, it was in fact due to their understanding of the limitations of initiatives. 
The gap between the aims of the initiative and the actual effects on students, therefore, stem from the disjunctures at previous stages (i.e. tensions between the democratic goals and the undemocratic nature the institution) as well as the exercising of the agency of the learners to reject or recast the messages.

\section{Understanding disjunctures in curricular transposition}

The empirical material presented above is too brief for a satisfactory analysis of the programme, but it does provide illustrations of how the disjunctures between different stages of curricular transposition work in practice. In the VF programme, educational activities are seen to exist in a relationship of separation from their goals, they struggle to find a meaningful presence in the curriculum in practice, and their effects on students depart from the original goals on account of the previous disjunctures and of student agency.

This article argues, therefore, that in order to understand citizenship education -- and thereby to provide more effective provision -- it is necessary to play close attention to the leaps from ends to means and from ideal to real. As stated above, there is a good deal of research on the processes of implementation and influences on learners (although much less on the relationship between ideal ends and means), yet these different phases need to be looked at in conjunction. The framework of curricular transposition provides a basis from which to analyse these processes. Nevertheless, further empirical research and theoretical discussion are necessary to understand the dynamics at work -- this study provides only an initial outline of the framework.

The key question that arises from curricular transposition is that of how to negotiate the three leaps, to cross the uncertain crevices between ends and means and between the ideal and the real. The implication of the curricular transposition framework is that successful negotiation of these leaps involves a form of 'harmony' or 'seamlessness' between the different stages. The exact nature of this seamlessness is a question that cannot be dealt with in full here. Yet, it is clear that unwitting disjunctures are a strong constraint on the effectiveness of initiatives.

A further element not addressed as yet is the absence of the fourth side of the square in the curricular transposition model. This fourth stage would link effects to the creation of new ideals of citizenship. A desire for completeness leads us to want to complete the figure, yet it is not clear whether the process is in fact or should be cyclical. The fourth side implies a modification of our ideals in the light of the effects of previous attempts to achieve them. One the one hand, this might seem like a rather cowardly course of action, abandoning our highest ideals when we see how difficult they are to achieve in practice. Yet from another perspective, if all the stages are in harmony, then our aspirations and ideals and are naturally modified and recreated in the light of new directions and insights. As Dewey emphasizes, ends are always beginnings:

Every means is a temporary end until we have attained it. Every end becomes a means of carrying activity further as soon as it is achieved. We call it end when it marks off the future direction of the activity in which we are engaged in; means when it marks off the present direction. (Dewey 1966: 106)

Clearly, it is the case that there is no final point at which there are 'effects' on students. As Dewey again states: "nothing happens which is final in the sense that it is not part of an ongoing stream of events" (Dewey 1964: 100). There is certainly, then, the possibility of a continuous momentum back from real to ideal, constituting the fourth leap. 
While the above discussion has assumed separate stages of curricular transposition, it is misleading to view them as discrete. They are neither chronologically separate, nor isolated from the influence of the others. The overarching aims are not always conceptualized prior to the means of achieving them, the curricular programme is often developed through implementation or developed only in relation to a particular context, and, as stated above, the effect on students is an ongoing process rather than an end state. In relation to the 'fourth side', the effects of the initiative can feed into decisions made in the design and implementation stages as well as modifying ideals and aspirations. Furthermore, there are particular approaches to the whole educational process which deliberately engage all the stages simultaneously so as to bring a more organic link between them. When complete harmony is attained, then the different stages disappear, or perhaps converge on a point. Nevertheless, it is analytically useful to separate the stages out in order to understand the various dynamics at work.

The framework of curricular transposition highlights instances of ingenuousness in existing and past citizenship education initiatives. Governments and other promoting bodies sometimes assume that it is sufficient to have a political aim and create an educational policy to achieve it, while ignoring the significant complexities of the educational undertaking. The framework of curricular transposition itself does not provide answers to the difficult questions of what ideals of citizenship should be promoted, of which educational activities are most effective, and how students learn. Nevertheless, it does draw attention towards the crucial questions themselves, and provides us with a lens through which to better understand the processes and the links between them.

\section{$\underline{\text { Acknowledgements }}$}

This article draws on $\mathrm{PhD}$ research carried out with funding from the UK Economic and Social Research Council, and supervised by Dr Elaine Unterhalter. 


\section{${ }^{1}$ Notes}

A further difference between this scheme and Perrenoud's is that in didactic transposition, the second stage involves the selections made by the institution of school, and the third stage those made by the individual teachers. In curricular transposition, the second stage represents the official curriculum and the third stage its implementation in practice, which includes factors relating to individual institutions and the wider societal context, as well as choices made by teachers.

${ }^{2}$ Eleitor do Futuro.

${ }^{3}$ In Brazil, voting is obligatory for people aged 18-70, with financial penalties for those who fail to vote. Those aged 16 and 17 are allowed to vote but are not obliged to do so.

${ }^{4}$ All the data collected was in Portuguese; the quotations appearing in the article are the author's translations to English.

${ }^{5}$ Pseudonyms have been used for participants and schools.

6 'Conscientization' (conscientização in the original Portuguese), a notion strongly associated with the work of Paulo Freire, signifies political awareness-raising leading to political action.

\section{References}

Bartlett L. (2005) Dialogue, knowledge, and teacher-student relations: Freirean pedagogy in theory and practice. Comparative Education Review, 49 (3), 344-364.

Benavot, A. and Resh, N. (2003) Educational governance, school autonomy, and curriculum implementation: a comparative study of Arab and Jewish schools in Israel. Journal of Curriculum Studies, 35 (2), 171196.

Bernstein, B. (1996) Pedagogy, Symbolic Control and Identity: theory, research, critique. London: Taylor \& Francis.

Bethell, L. (2000) Politics in Brazil: from elections without democracy to democracy without citizenship. Daedalus, 129 (2): 1-27.

Burges, S. (2006) Informing Young People of the Need for Conscientious Voting: Eleitor do Futuro (Voter of the Future) in Brazil. In A. Ellis, M. Gratschew, J. Pammett and E. Thiessen (Eds), Engaging the Electorate: Initiatives to Promote Voter Turnout From Around the World. Strömsborg: International IDEA.

Callan, E. (1997) Creating citizens: political education and liberal democracy. Oxford: Clarendon.

Chevallard, Y. (1985) La transposition didactique. Du savoir savant au savoir enseigné. Grenoble: La Pensée Sauvage.

Cogan, J. J. and Morris, P. (Eds.) (2001). The development of civic values in six Pacific Rim societies. Special Issue of the International Journal of Educational Research, 35 (1), 1-123.

Conne, F. (1992). Savoir et connaissance dans la perspective de la transposition didactique. Recherches en didactique des mathématiques, 12(2/3), 221-270.

Davies, I. and Issitt, J. (2005) Reflections on citizenship education in Australia, Canada and England. Comparative Education, 41 (4), 389-410.

Dewey, J. (1966) Democracy and Education. London: Collier-Macmillan. 
Dewey, J. (1964) The Continuum of Ends-Means, In R. Archambault (Ed.) John Dewey on Education: Selected Writings. Chicago: University of Chicago Press.

Finkel, S. (2002) Civic Education and the Mobilisation of Political Participation in Developing Democracies. The Journal of Politics. 64 (4) 994-1020.

Fullan, M. and Pomfret, A. (1977) Research on curriculum and instruction implementation. Review of Educational Research. 47 (2), 335-397.

Galston, W. (2002) Liberal Pluralism: the Implications of Value Pluralism Political Theory and Practice. Cambridge: Cambridge University Press.

Gandin, L., and Apple, M. W. (2002) Challenging Neo-Liberalism, Building Democracy: Creating the Citizen School in Porto Alegre, Brazil. Journal of Education Policy, 17(2), 259-279.

Gastil, J. (2004) Adult Civic Education through the National Issues Forums: Developing Democratic Habits and Dispositions through Public Deliberation. Adult Education Quarterly, 54 (4), 308-328.

Gentili, P., and Frigotto, G. (Eds) (2000) A Cidadania Negada: políticas de exclusão na educação e no trabalho. Buenos Aires: CLACSO.

Gentili, P., and McCowan (Eds) (2003) Reinventar a Escola Publica: politica educacional para um novo Brasil. Petropolis: Vozes.

Green, A. (1990) Education and state formation: the rise of education systems in England, France and the USA. London: Macmillan.

Kymlicka, W. (2003) Multicultural States and Intercultural Citizens. Theory and Research in Education, 1, $147-169$.

McAllister, I. (1998) Civic Education and Political Knowledge in Australia. Australian Journal of Political Science, 33 (1), 7-23.

McCowan, T. (2009) Towards an Understanding of the Means-Ends Relationship in Citizenship Education. Journal of Curriculum Studies, 41 (3), 321-342.

McCowan, T. (2006) Educating citizens for participatory democracy: a case study of local government education policy in Pelotas, Brazil. International Journal of Educational Development, 26 (5), 456470.

McCowan, T. (2003) Participation and Education in the Landless People's Movement of Brazil. Journal for Critical Education Policy Studies, 1(1). http://www.jceps.com/index.php?pageID=article\&articleID=6

McLaughlin, T. H. (1992) Citizenship, Diversity and Education: a philosophical perspective. Journal of Moral Education, 21(3), 235-250.

Miller, R. (2007) Unlearning American patriotism. Theory and Research in Education, 5, 7 - 21.

Mullis, I., Martin, M., Ruddock, G., O’Sullivan, C., Arora, A. and Erberber, E. (2005) TIMSS 2007 Assessment Frameworks. Boston: TIMSS \& PIRLS International Study Center.

Myers, J, (2007) Citizenship Education Practices of Politically Active Teachers in Porto Alegre, Brazil and Toronto, Canada. Comparative Education Review, 51 (1), 1-24.

Niemi, R. and Junn, J. (1998) Civic Education: What Makes Students Learn. New Haven: Yale University Press. 
Osler, A., and Starkey, H. (2001) Citizenship Education and National Identities in France and England: inclusive or exclusive? Oxford Review of Education, 27(2), 287-305.

Perrenoud, P. (1986) Vers une lecture sociologique de la transposition didactique. Geneva: Université de Genève, Faculté de psychologie et des sciences de l'éducation

Perrenoud, P. (1998) La transposition didactique à partir de pratiques: des savoirs aux competences. Revue des sciences de l'éducation, 24 (3), 487-514.

Snyder, J., Bolin, F. \& Zumwalt, K. (1992) Curriculum Implementation. In P. Jackson (Ed.) Handbook of Research on Curriculum. New York: Macmillan.

Stromquist, N. (1997) Literacy for Citizenship: Gender and Grassroots Dynamics in Brazil. New York, Albany.

Taylor, L. (2004) Client-ship and Citizenship in Latin America. Bulletin of Latin American Research. 23 (2), 213-227.

Tochon, F.V. (1991) Entre didactique et pédagogie: épistémologie de l'espace/temps stratégique. Revue de la pensée éducative, 25, 120-133.

Torney-Purta, J., Schwille, J. and Amadeo, J.-O. (1999) Civic Education Across Countries: Twenty-Four National Case Studies for the IEA Civic Education Project. Amsterdam: IEA.

Walkington, H. and Wilkins, K. (2000) Education for critical citizenship: the impact of teachers' world-view on classroom practice in the teaching of values. The School Field. 11 (1/2), 59-78.

\section{Documentary sources}

RET (Regional Electoral Tribunal) (2006) Regulamentos do Referendo.

RET (2005) Programa Eleitor do Futuro.

RET (2004) Programa Eleitor do Futuro.

SET (Supreme Electoral Tribunal) (2003) Projeto Eleitor do Futuro: Aprendendo a Ser Cidadão [Learning to be a Citizen]. 